\title{
TEISË
}

\section{M. GEGUŽĖS 3-IOSIOS KONSTITUCIJA IR LIETUVOS KONSTITUCINGUMO TRADICIJA}

Doc. DR. VAIDOTAS A. VAIČAitis

Vilniaus universiteto Teises fakulteto

Viešosios teisès katedra

Vilnius University Faculty of Law

Department of Public Law

Sauletekio al. 9-405, Vilnius

El.paštasvaidotas1@hotmail.com

\section{Santrauka}

Straipsnyje pateikiamas trumpas $1791 \mathrm{~m}$. gegužes 3-iosios Konstitucijos tyrimas Lietuvos konstitucinès teisès požiūriu, kuriuo norima paskatinti Lietuvos konstitucinès teisès specialisty diskusija dèl Konstitucijos vertinimo. Tai padaryti yra bütina, nes iki šiol šio dokumento svarba buvo nagrineta praktiškai išimtinai Lietuvos istoriku darbuose. Straipsni sudaro trys dalys: $1791 \mathrm{~m}$. gegužès $3 \mathrm{~d}$. Konstitucija ir šiuolaikine konstitucingumo tradicija; Gegužés 3-iosios Konstitucija ir Lietuvos matmuo; Gegužés 3-iosios Konstitucija kaip sudètinès Abiejų Tautu Respublikos $1791 \mathrm{~m}$. Konstitucijos dalis.

Straipsnis baigiamas išvadomis, iš kuriu svarbiausia yra ta, jog Lietuvos konstitucingumo tradicijos šaltiniu siūloma laikyti sudètinę $1791 \mathrm{~m}$. Abieju Tautu Respublikos Konstitucija, kuriq sudarytu keturi konstituciniai aktai: Gegužès 3-iosios Valdymo ịstatymas (su Gegužés 5 d. Seimo deklaracija), $1791 \mathrm{~m}$. kovo $24 \mathrm{~d}$. Seimeliu įstatymas, $1791 \mathrm{~m}$. balandžio 21 d. Miestu istatymas ir $1791 \mathrm{~m}$. spalio 20 d. Abieju Tautu Tarpusavio 
Isipareigojimas, kuris, vertinant Lietuvos konstitucingumo požiūriu, yra esminis konstitucinis aktas, leidžiantis visus minetus Ketveriu metu Seimo konstitucinius aktus perskaityti Lietuvos konstitucingumo tradicijos kontekste.

Reikšminiai žodžiai: Konstitucija; Seimas; Lietuva; Abiejų Tautų Respublika; $1791 \mathrm{~m}$.

\section{Ivadas}

\section{LIETUVIU TAUTA}

- prieš daugeli amžiu sukūrusi Lietuvos valstybę

- jos teisinius pamatus grindusi Lietuvos Statutais ir Lietuvos Respublikos Konstitucijomis <...>

Iš 1992 m. Lietuvos Respublikos Konstitucijos preambulès

Gegužès 3-iosios Konstitucija, be abejonès, gali būti vadinama didžiojo naratyvo ir istorinès bei kultūrinès „atminties vieta“, nes su jos priemimu, (ne)galiojimu ir tekstiniu turiniu susijusios skirtingos interpretacijos Lietuvoje, Lenkijoje ir kitų Europos ir pasaulio valstybių istoriografijoje. Lenkijoje daugelis miestelių turi gatves, pavadintas „3-ego Maja“, be to, Gegužès 3-ioji Lenkijoje yra nedarbo diena, kartu tai yra tautos vienybès ir pasididžiavimo diena. Atsakymas ị klausimą, kaip šis dokumentas yra vertinamas Lietuvoje, nèra vienareikšmis. Šio atsakymo paieškos veda ị lietuvių ir lenkų tautinio atgimimo bei nacionalinių valstybių kūrimo laikotarpi prieš ir po Pirmojo pasaulinio karo. Nacionalinès etninès tautòs, kaip valstybès kūrèjos ir politinio suvereniteto subjekto, samprata buvo būdinga praktiškai visoms tuo metu su(at)sikūrusioms Europos valstybėms. Šis XIX a. pab.-XX a. pr. lietuvių tautos atsiribojimo nuo lenkų tautos judesys lèmé ir vadinamojo lietuviškojo istorijos didžiojo naratyvo konstravimą, kuriame praktiškai neliko vietos lietuvių ir lenkų santykių sąlyčio taškams arba 
jie dažniausiai buvo vaizduojami neigiamame kontekste. Panašiai atsitiko ir vertinant Gegužès 3-iosios Konstituciją ir kitus Ketverių metų Seimo konstitucinius aktus, neradusius vietos Lietuvos didžiojo naratyvo pasakojime. Tai iš dalies atsispindi ir 1992 m. Lietuvos Respublikos Konstitucijos preambuleje, kurios nuorodoje ị konstitucinius ir teisinius Lietuvos šaltinius nuo XVI amžiaus Lietuvos statutų iš karto peršokama į XX a. Pirmosios Lietuvos Respublikos konstitucijas.

Gegužès 3-iosios Konstitucijos reikšmès permąstymas Lietuvos konstitucingumo kontekste, ypač po Lietuvos Respublikos Seimo $2007 \mathrm{~m}$. balandžio $17 \mathrm{~d}$. ir $2011 \mathrm{~m}$. balandžio $28 \mathrm{~d}$. rezoliucijų prièmi$\mathrm{mo}^{1}$, galètų tam puikiai pasitarnauti, turint omenyje pastarosios rezoliucijos nuostatą, pagal kurią pirmoji Europoje Konstitucija yra „Gegužés trečiosios Konstitucija su Abieju Tautų tarpusavio įžadu“.

Pagrindinis straipsnio tikslas - pabandyti ištirti $1791 \mathrm{~m}$. gegužès 3-iosios Konstitucijos sąsajas su Lietuva ir pradèti diskusiją apie tai, ar immanoma ši ir kitus Ketverių metų Seimo konstitucinius aktus ịtraukti ne tik $\mathfrak{i}$ Lietuvos istorijos didiji naratyvą, bet ir $\mathfrak{i}$ Lietuvos konstitucingumo tradiciją. Kitais žodžiais tariant, šiuo straipsniu nesistengiama paneigti didžiojo ar metanaratyvo valstybès (ir tautos) istorijoje būtinybės, nes manytina, kad taikiai gali sugyventi keli naratyvai, iš kurių vienam vis dèlto galima teikti pirmenybę. Pagrindinis tyrimo objektas ir šaltinis yra Gegužès 3-iosios Konstitucija ir kiti su ja susiję $1791 \mathrm{~m}$. konstituciniai teisès aktai. Pagrindiniai tyrimo metodai: aprašomasis, lyginamasis ir analitinis.

1 Valstybès žinios. 2007, Nr. 48-1855; 2011, Nr. 53-2542. Pirmosios rezoliucijos tekstas atpasakoja labiau ,lenkiškos“ Abiejų Tautų Respublikos naratyvą, pagal kurị Abiejų Tautų Respubliką reikètų vertinti kaip vieną iš pirmujų Europos valstybių vienijimosi pavyzdžių, t. y. tarsi Europos Sajungos pirmtakę. Savo ruožtu antroji rezoliucija bando kurti ,lietuviškajị “ Respublikos ir Gegužès 3-iosios Konstitucijos naratyvą. Ypač paminėtina $2011 \mathrm{~m}$. rezoliucijos nuostata, kad ,Seimas <..> pabrèždamas, kad Gegužès trečiosios Konstitucija su Abiejų Tautų tarpusavio įžadu yra pirmoji moderni rašytinė Konstitucija Europoje ir antroji rašytinė Konstitucija pasaulyje“. 
Svarbu taip pat paminèti, jog straipsnyje laikomasi nuomonès, kad XX a. pab. atsikūrusi Lietuvos Respublika valstybingumo aspektu yra viduramžių Lietuvos Didžiosios Kunigaikštystès, kaip Lietuvos valstybès, tęsinys, nepaisant to, jog tiek lietuvių tautòs (pvz., bajoriškosios, pilietinès, etninès), tiek suvereno samprata skirtingais laikotarpiais mūsų valstybejje buvo suprantama skirtingai (tokiam požiūriui atliepia ne tik 1992 m. Konstitucijos nuoroda i Vilnių, kaip Lietuvos valstybès sostinę, bet ir jau minèta jos preambulès nuoroda $\mathfrak{i}$ „prieš daugelị amžių“ sukurtą Lietuvos valstybę ir XVI a. Lietuvos statutus, kaip šios valstybès „teisinius pamatus“).

\section{I. $1791 \mathrm{~m}$. gegužès 3 d. Konstitucija ir šiuolaikinė konstitucingumo tradicija}

Pirmiausia reikètų užduoti klausimą, ar Gegužès 3-iosios Konstitucija (nepaisant jos trumpo galiojimo) yra konstitucija moderniąja prasme, kurios prototipu visuotinai laikoma 1787 m. JAV Konstitucija? Kitais žodžiais tariant, šioje dalyje pavadinimas nebus nagrinėjamas: ar dokumentą drąsiai galima vadinti konstitucija, ar reikètų grị̌žti prie jo originalaus pavadinimo Valdymo ịstatymas (lenk. Ustawa rządowa). Kadangi jau nuo dokumento prièmimo momento tiek Seimo, tiek ir visuomenès jis buvo vadinamas konstitucija, vèlesnèse jo publikacijose nusistovèjo pavadinimas „Gegužès 3-iosios Konstitucija“ (beje, šio dokumento turinyje net 24 kartus jis pavadinamas konstitucija). Reikalą kiek komplikuoja tai, kad terminas Seimo konstitucija jau nuo XVI a. Abiejų Tautų Respublikos teisinejje sistemoje buvo vartojamas įvardijant tam tikrą ordinarinị Seimo įstatymą arba įstatymų paketą (lot. constitutiones, lenk. konstytucja sejmowa).

Reikètų pabrèžti, kad terminas konstitucija ị Renesanso ir Apšvietos laikotarpio teisinę vartoseną (pirmiausia per kanonų teisę) atėjo iš romėnų teisès tradicijos, kur terminu constitutiones buvo įvardija- 
mi tam tikri svarbūs imperatoriaus ediktai ${ }^{2}$. Vis dèlto svarbiausia ne tiek terminas, kiek tam tikros moderniosios konstitucijos savybès, leidžiančios konkretų dokumentą priskirti modernių konstitucijų kategorijai. Nesigilinant $\mathfrak{i}$ konstitucionalizmo teoriją, galima išskirti tris svarbiausias konstitucijos savybes (principus): 1) pirmiausia konstitucija, kaip steigiamasis aktas ir iš to kylanti jos viršenybė prieš kitus teisès aktus, bei sudètingesnè jos prièmimo ir keitimo tvarka, 2) joje numatyta (dažniausiai nauja) valstybès valdžios sandara ir užfiksuotas valdžių padalijo principas bei 3) (tam tikros) žmogaus teisių garantijos $^{3}$. Šie trys principai daugiau ar mažiau atsispindi tiek 1787 m. JAV Konstitucijoje, tiek ir 1789 m. Prancūzijos Žmogaus ir piliečio teisių deklaracijoje, kurios XVI straipsnyje gana kategoriškai teigiama: „Visuomene, kurioje (žmogaus) teisiu garantijos nèra užtikrintos ir valdžiu padalijimas nèra ịtvirtintas, neturi Konstitucijos". Tačiau teisybès dèlei reikia pasakyti, kad XVIII a. pab. konstitucijose (t. y. pirmosiose konstitucijose) verta labiau ieškoti šių principų užuomazgų, o ne galutinio išplètojimo, nes priešingu atveju konstitucijos titulo negalètume suteikti net, pavyzdžiui, $1814 \mathrm{~m}$. Norvegijos Konstitucijai (visuotinai laikomai vienai iš pirmųjų pasaulio konstitucijų), kurioje užfiksuotos tik kuklios kai kurių minètų principų užuomazgos.

1. Vertinant pirmąją konstitucijų savybę reikia pripažinti, kad Gegužès 3-iosios Konstitucijos steigiamasis pobūdis ${ }^{4}$ atsiskleidžia ne tik tuo, jog numato naujas institucijas, tokias kaip Istatymų Sargyba, bet pirmiausia tuo,

2 Nekrošius, I., Nekrošius, V., Vèlyvis, S. Romennu teisè. Kaunas: Vijusta, 1996, p. 20-21.

3 Tiesioginis konstitucijos taikymas teismuose nèra minimas, nes šis konstitucijos principas kontinentinejje Europoje galutinai įsitvirtino tik po Antrojo pasaulinio karo.

4 Steigiamasis aktas yra tas, kuris steigia iki tol neegzistavusią teisinę visuomeninę tikrovę. Išsamiau apie steigiamajį konstitucijos pobūdį žr.: Vaičaitis, V. Suvereniteto samprata ir 1992 m. Lietuvos Respublikos Konstitucija. Lietuvos Respublikos Konstitucijos dvidešimtmetis: patirtis ir iššükiai. Vilnius, 2012, p. 106-114; Vaičaitis, V. 1949 m. vasario 16-osios Lietuvos laisvès kovos sajūdžio tarybos deklaracija ir jos reikšmé Lietuvos Respublikos teisinei sistemai. Nepriklausomos Lietuvos teisé: praeitis, dabartis ir ateitis. Vilnius, 2012. 
kad steigia visai naują valstybės valdymo formą - konstitucinę paveldimą monarchiją. Todèl (tiesa, plačiąja prasme) Gegužès 3-iosios Konstituciją galima ịtraukti ị valdovo ir bajorų sudaromų pacta conventa sąrašą, nes tokiu aktu valdovas ir bajorai sudarydavo visai naują tarpusavio sutartį dèl valstybès valdymo, o tokie pacta conventa šiuolaikiniu požiūriu visuomet yra valstybės konstituciniai aktai ${ }^{5}$. Taip pat pabrěžtina, kad Konstitucijos tekste užfiksuota jos viršenybe prieš kitus Seimo aktus, o tai ją išskiria iš kitų Seimo konstitucijų-įstatymų. Preambulëje ir VI straipsnyje apie šią Konstituciją teigiama: „Skelbiame ja šventa ir neliečiama, kol tauta istatymo numatytu laiku savo aiškia valia pripažins būtina pakeisti joje koki nors straipsni <...>, šią konstitucija visame kame turi atitikti kiti dabartinio Seimo išleisimi įstatymai <...>“; „Užkirsdami kelią šiurkštiems ir dažniems tautos konstitucijos keitimams iš vienos pusès ir pripažindami būtinybę ja tobulinti <...> skiriame meta ir laikg Konstitucijai peržiūrèti ir pataisyti kas dvidešimt penkerius metus"6. Taigi, tai nèra eilinis ordinarinis Seimo istatymas, nes šis dokumentas turèjo bent jau iki $1816 \mathrm{~m}$. galioti nekeičiamas ${ }^{7}$. Tačiau šios Konstitucijos viršenybès principą kiek komplikuoja tai, kad joje nèra numatyta sudètingesnè jos prièmimo tvarka, palyginti su paprastais Seimo ịstatymais, kaip tai, pavyzdžiui, numatyta $1787 \mathrm{~m}$. JAV Konstitucijoje ir iš dalies $1791 \mathrm{~m}$. rugsèjo $3 \mathrm{~d}$. Prancūzijos Konstitucijoje. Dar daugiau, nors 1791 m. gegužès 5 d. Seime perbalsuojant dèl Konstitu-

5 Vis dèlto istoriografija pacta conventa atsiradimą Abiejų Tautų Respublikos istorijoje sieja su $1573 \mathrm{~m}$. Henriko (Henry de Valois) artikulais, kuriuose atsispindèjo naujojo renkamo Respublikos valdovo - sutartis su jị išrinkusiais bajorais, o Gegužès 3-iosios Konstitucijoje buvo vèl grižtama prie sosto paveldejimo. Kita vertus, konstitucinio rango dokumentams galima priskirti kiekvieną LDK ar Abiejų Tautų Respublikos valdovo privilegiją, iskaitant ir Lietuvos statutus, turinčius valdovo privilegijos, t. y. jo sutarties su bajorais, požymių. Žr. Machovenko, J. Piliečio ir valstybės santykiai 1791 m. gegužès 3 d. Konstitucijoje: paveldas ir pamoka. Lietuvos Respublikos Konstitucijos dvidešimtmetis: patirtis ir iššükiai. Vilnius, 2012, p. 8.

6 Čia ir toliau bus naudojamasi Eligijaus Railos ị lietuvių kalbą išverstu Konstitucijos tekstu, žr. Raila, E. Apie 1791 gegužès 3-iosios konstitucija. Vilnius: Aidai, 2007.

7 Analogiškos nuomonès apie šios Konstitucijos viršenybę prieš kitus Seimo aktus laikosi ir lenkų istorikas Michałas Petrzakas, žr. jo studiją: Petrzak, M. Konstytucja 3 Maja 1791 roku. Warszawa: Wydawnictwo Sejmowe, 2011, p. 4, 10. 
cijos, ji buvo patvirtinta vienbalsiai ${ }^{8}$, tačiau ją priimant nebuvo išlaikytos reikiamos „deliberacijos“ procedūros, taikytos Reformų (Ketverių metų) Seimo. Kitais žodžiais tariant, Gegužès 3-iosios Konstitucija buvo priimta (antrą kartą balsuojant dèl jos gegužès 5 d.) formaliai nesilaikant Seimo konstitucijų prièmimo reikalavimų, apeliuojant ị valstybès situacijos sudètingumą, išimtinę padètį ar force majeure ${ }^{9}$. Kita vertus, nors Konstitucijos tekste jos keitimo tvarkai ir nèra nustatytas ypatingos daugumos reikalavimas, tačiau dèl 25 metu , apmąstymo “ traktuotinas kaip sąlygojantis išskirtinai sudètingą jos keitimo tvarką (kuri taip niekada ir nebuvo praktiškai pritaikyta jokioje pasaulio valstybeje).

Su Konstitucijos steigiamuoju pobūdžiu labai susijusi ir tautos - suvereno - samprata. Tačiau reikia pripažinti, kad terminas tauta Konstitucijos tekste vartojamas dviprasmiškai, t. y. dvejopa prasme: viena vertus, pagal Jeano-Jacqueso Rousseau ideją tautos samprata apima visus gyventojus, ịskaitant ir žemdirbius valstiečius (IV str.), kita vertus, tauta ir piliečiais vadinami išimtinai bajorai (šlèktos), turintys teisę dalyvauti ìstatymų leidyboje ir sprendžiant kitus valstybès klausimus (VI str. $3 \mathrm{~d}$. 1 p., VI str. 8 d.) Seime ir seimeliuose ${ }^{10}$. Be to, ir Konstitucija priimama ne visuotinos (pilietinès) tautos, o karaliaus, kaip tautos valios reiškejjo, ir Seimo atstovų, t. y. vyriškos giminès bajoriškosios tautos atstovų, pritarimu ${ }^{11}$.

8 Kochlewski, W. Ustawa Rzqdowa. Konstytucja 3 Maja 1791: pierwodruki. Warszawa, 2005, p. 3. Teisybės dèlei reikia pasakyti, kad tie Seimo atstovai, kurie nepritare Konstitucijai, tiesiog nedalyvavo gegužès $5 \mathrm{~d}$. Seimo posėdyje.

9 Šapoka, A. Raštai. T. 2. Lietuva Reformu Seimo metu. Iki 1791 m. Gegužès 3 d. Konstitucijos. Vilnius: Vilniaus pedagoginio universiteto leidykla, 2008, p. 415.

${ }^{10}$ Dviprasmę tautos sampratą Konstitucijoje (lenk. dwojakie znaczenie terminu naród) pastebejo ir lenkų istorikas Michałas Petrzakas, žr.: Petrzak, M. Konstytucja 3 Maja 1791 roku. Warszawa: Wydawnictwo Sejmowe, 2011, p. 9.

${ }^{11}$ Būtent bajorai Konstitucijoje ìvardijami „konstitucijos gynejais“ (II str.). Aišku, būtina pastebėti, kad pilietinès tautos, kaip visų valstybės gyventojų, piliečių visumos samprata XVIII a. dar nebuvo ịtvirtinta jokioje valstybèje. Pvz., Prancūzijos $1791 \mathrm{~m}$. Konstitucija pilietines teises numate tik gyventojams vyrams, mokantiems ne mažesnį kaip trijų darbo dienų mokestị, o JAV Konstitucija pilietinių teisių nesuteikè ne tik moterims, bet ir vietiniams indènams. 
2. Kitas svarbus modernios konstitucijos bruožas, nustatytas Gegužès 3-iosios Konstitucijos tekste, yra jau minèta nauja valdžios sandara ir valdžių padalijimas. Konstitucijoje keičiama valstybès valdymo forma: iš bajorų demokratijos su renkamu monarchu i paveldimą monarchiją iš Saksonijos elektorių; Konstitucija sustiprina miestiečių padètị ir sudaro sąlygas formuotis trečiajam luomui (su galimybe dalyvauti Seime) ir kas dar svarbiau - pirmąkart konstituciniu lygmeniu įtvirtina valstiečių teisinę padètį, jiems suteikdama specialų konstitucinị teisinị statusą. İdomu tai, kad Konstitucija, konstitucionalizavusi $1791 \mathrm{~m}$. kovo 24 d. Seimelių ístatymą, kartu susiaurino iki tol Respublikoje egzistavusią bajoriškosios tautos sampratą, bežemiams šlèktoms (plikbajoriams) uždrausdama dalyvauti vietos seimeliuose, rinkusiuose Seimo atstovus. Aišku, būtina pripažinti, kad Abiejų Tautų Respublikos Konstitucija, skirtingai nei tų pačių metų Prancūzijos Konstitucija, nepretendavo panaikinti luominę santvarką ir ịvesti visuotinę piliečio sampratą. Vis dèlto Gegužès 3-iosios Konstitucijoje atsispindi minètas valdžių padalijimo principas, prieš beveik dvejus metus deklaruotas Prancūzijos Žmogaus ir piliečio teisių deklaracijoje. Pavyzdžiui, Konstitucijos V straipsnyje teigiama: „Idant Respublikos valstybiu vientisumas, pilietine laisve ir visuomenès tvarka visam laikui išliktu pusiausvyroje, lenku tautos valdymą turi sudaryti trys valdžios <...>, tai yra: Istatymų leidžiamoji valdžia luomu susirinkimas (w stanach zgromadzonych); Aukščiausioji vykdomoji valdžia - karalius bei Sargyba; Teismine valdžia - šiam tikslui įkurtuose teisminiuose organuose ( $w$ juryzdykcyach)“. Labai svarbu paminèti, kad Konstitucija atskyrè ne tik legislatyvinę valdžią nuo vykdomosios (nors karalius turejjo pirmininkauti Senatui), bet ir atribojo teisminę valdžią nuo kitų dviejų: „Teisminè valdžia negali būti vykdoma nei įstatymų leidžiamosios valdžios, nei karaliaus, o tik šiam tikslui isteigtų ir išrinktu magistratūrü"(VIII str.).

3. Vertinant Gegužès 3-iosios Konstitucijos santykị su trečiąja minèta moderniõs konstitucijos savybe (žmogaus teisių lygmuo), reikia pripažinti, kad žmogaus teisès (kaip prigimtinès) šiuolaikiniu požiūriu garan- 
tuotos nebuvo, nes nebuvo panaikinta baudžiava ir valstybės luominè santvarka, kaip tai buvo padaryta po keturių ménesių priimtoje pirmoje Prancūzijos Konstitucijoje. Aišku, tam tikras, nors ir minimalus, judesys šia linkme buvo. Pirmiausia, kaip minèta, valstiečiams Konstitucijoje skirtas atskiras IV straipsnis „Valstiečiai“ (lenk. “Chłopi Włościanie”), kuriame valstiečiai įvardijami kaip žmonès, „iš kuriu rankų trykšta gausiausia krašto turtu versmè ir kurie sudaro didžiausia tautos gyventojų dalį. Dar daugiau - jie Konstitucijos „priimami teisès ir krašto valdymo globon“, o dvarininkų ir valstiečių susitarimai, „surašyti teisingomis salygomis taps bendru ir abipusiu isipareigojimu“, kurių žemès savininkai „niekada savavališkai negales pakeisti“ (IV straipsnis). Taip pat svarbu paminèti, kad šiame straipsnyje numatyta visiška laisvè naujai atvykstantiems ị Respubliką asmenims (pvz., sentikiams ar kitiems asmenims, bėgusiems iš Rusijos) bei tiems, kurie anksčiau iš krašto pasišalinę, dabar norètų i tèvynę grị̌zi, pavyzdžiui, kiekvienas naujai atvykęs žmogus „turi visišką laisvę užsiimti savo amatu, turi laisvę sudaryti sutartis dèl gyvenamosios vietos, darbo atlygio ar činšu tokiam laikui, kokiam susitars, turi laisvę isikurti mieste ar kaimuose“. Taigi, Konstitucijos IV straipsnio formuluotès dvelkia Apšvietos lygybès dvasia ir tarsi ignoruoja luominę baudžiavinę Abiejų Tautų Respublikos tikrovę.

Apibendrinant šią dalį galima konstatuoti, kad $1791 \mathrm{~m}$. gegužès 3-iosios Valdymo įstatymas, nors priimtas ne Stanislovui Augustui įžengiant i sostą, o jo valdymo pabaigoje, turi valdovo ir bajorijos tarpusavio sutarties teisinị svorị, nes iš naujo performuluoja valdovo ir bajorijos anksčiau sutartą valstybės valdymo formą ir principus (pirmiausia nustatė paveldimą konstitucinę monarchiją vietoj anksčiau galiojusio renkamo valdovo, dèl šio pakeitimo monarchas iškilmingai prisiekẻ Seime), todèl dabartinèje teisinèje terminijoje toks aktas galètų būti vadinamas konstituciniu. Be to, pagal turinị Konstitucija daugiau ar mažiau atitinka ir šiuolaikinès konstitucijos požymius, todèl istoriografijoje ir žmonių sąmonèje plačiai paplitęs jos įvardijimas konstitucija yra teisiškai pagrịstas net vertinant šiuolaikinès teisinès terminijos požiūriu. 


\section{Gegužès 3-iosios konstitucija ir Lietuvos valstybingumo matmuo}

Viena iš didžiausių kliūčių Gegužès 3-iosios konstituciją priskirti Lietuvos konstitucinei tradicijai yra ta, kad jos tekste nei valstybingumo, nei tautos matmenyse nèra kalbama apie Lietuvą ar LDK, o rašant apie tautą išimtinai minima lenkų tauta. Dèl šios priežasties Pirmosios Lietuvos Respublikos istoriografijoje nusistovejo tradicija (kuri vèliau ịejo ị vadinamąji Lietuvos istorijos didijį naratyvą) Konstituciją Lietuvos valstybingumo požiūriu vertinti neigiamai, pabrěžiant, kad ja buvo panaikinta Abiejų Tautų Respublika, kaip konfederacinė valstybė, ir konstituciniu lygmeniu itteisinti tik Lenkijos kraštu ( $w$ krajach polskich), Lenkijos žemès (ziemia polska) ir provinciju terminai ${ }^{12}$.

O ką gi liudija Konstitucijos tekstas? Galima pacituoti keletą dokumento nuostatų: „Stanislovas Augustas <...> drauge su dvigubos sudeties konfederuotu seimu, atstovaujančiu lenku tautai" (Preambulè); „<...>garantuojame visu apeigu ir religiju laisvę Lenkijos kraštuose, pagal kraštu jstatymus“ (I str.); „šiame seime priimta istatyma, <...> suteikianti naują, tikra ir veiksminga jèga laisviems lenku bajorams“ (III str.); „kiekvienas žmogus, <...> vos įžengęs ị lenku žemę, turi visiška laisvę“ (IV str.); „Idant valstybiu vientisumas, pilietine laisvè ir visuomenés tvarka visam laikui išliktu pusiausvyroje, lenku tautos valdyma turi sudaryti trys valdžios" (V str.); „<...> todel laisvajai lenku tautai laidave galimybę kurti sau įstatymų valdžią <...>“; „<...> pareiga apsaugoti kiekvieno lenkü žemès gyven-

${ }^{2}$ Tokị iki šių laikų Lietuvoje įsitvirtinusị požiūrị puikiai ịkūnija vienas iš Justino Marcinkevičiaus dramos „Katedra“ herojų - Žmogus:

„Reik paminet, kad tūkstantis septyni

Šimtai devyniasdešimt pirmu metu

Valstybès konstitucijoj nèra

Net žodžio „Lietuva“. Vadinas, broliai,

Mes stovim prie tèvynès kapo...".

Marcinkevičius, J. Katedra: dešimties giesmių drama. Mindangas. Mažvydas. Katedra. Kaunas: Šviesa, 1988, p. 267. 
tojo likimą ir visiems laikams užkirsti keliq užsienio valstybiu ịtakai, <...> būtinybe nukreipti nuo sosto svetimšaliu ir įtakingų lenkų ambicijas <... > (VII str.). Taigi, iš cituotų Konstitucijos nuostatų galima daryti išvadą, kad dèl šios Konstitucijos LDK galutinai praranda savo turètą konfederacijos subjekto juridinị statusą ir tampa tiesiog ziemia polska, o LDK bajorai nuo šiol traktuojami kaip priklausantys lenkų tautai - naród polski (tiesa, lieka neaišku, ar šalia natione polonus LDK bajorai pagal Konstituciją galètų save vadinti bent jau gente lituanus).

Reikia pripažinti, kad vienu iš pirmųjų bandymų perskaityti Gegužès 3-iosios konstituciją „lietuviškai“ galima laikyti Adolfo Šapokos darbus, kuriuose jis dar tarpukariu stengèsi išsiaiškinti LDK atstovų poziciją šiuo klausimu ir žvelgti ị ją $1791 \mathrm{~m}$. spalio $20 \mathrm{~d}$. Abiejų Tautų Tarpusavio İsipareigojimo $^{13}$ akto kontekste. Pirmiausia turima omenyje nepublikuota A. Šapokos studija „Lietuva Reformų Seimo Metu“14 (parengta 1936 m. disertacijos pagrindu) ir Konstitucijai skirtas straipsnis ${ }^{15}$. Vis delto autorius Konstitucijos prièmimą gegužès 3 ir 5 dienomis vadina tikru perversmu ar coup d'etat ${ }^{16}$, juolab kad šiuo aktu buvo pažeistos ankstesnès monarcho ir bajorų pacta conventa (pirmiausia nuostata, kad bajorai turi

${ }^{13}$ Nors kai kurie autoriai šị dokumentą verčia kaip „Ižadą“ (iš lenk. zeręczenie), autorius laikosi termino „Isipareigojimas“, kuris labiau tinkamas šiuolaikinei teisinei kalbai.

14 Šapoka, A. Raštai. T. 2. Lietuva Reformu Seimo metu. Iki 1791 m. Gegužès 3 d. Konstitucijos. Vilnius: Vilniaus pedagoginio universiteto leidykla, 2008.

15 Šapoka, A. Gegužès 3 d. konstitucija ir Lietuva. Lietuvos praeitis. Kaunas, 1940, t. 1, sąs. 1, p. 137-210.

${ }^{16}$ Tokị jo požiūrị greičiausiai lèmè tai, kad nebuvo laikomasi formalių konstitucijos prièmimo taisyklių, pagal kurias kiekvienas Keturmečio Seimo konstitucijos projektas po perskaitymo Seime turèjo būti perduotas ,deliberacijai“ konstitucinèje komisijoje ir bent 3 dienas prieš sprendimo priemimą išdalytas atstovams susipažinti. Be to, atstovai Seime vietos seimeliuose gaudavo instrukcijas (igaliojimus), kaip reikia balsuoti Seime, o balsavimas už tokią valdymo formą, kurioje būtų apribota bajorų teisè rinkti valdovą, dažniausiai peržengè Seimo atstovų turètų instrukcijų ribas. Galų gale tokia valdymo formos pataisa (sosto paveldejjimas) prieštaravo ir valdovo su bajorija sudarytai pacta conventa. Žr. Šapoka, A. Raštai. T. 2. Lietuva Reformu Seimo metu. Iki $1791 \mathrm{~m}$. Gegužès 3 d. Konstitucijos. Vilnius: Vilniaus pedagoginio universiteto leidykla, 2008, p. 399, 407. 
teisę rinkti monarchą). Kita vertus, būtent A. Šapoka pirmasis pabrèžè, kad Gegužès 3-iosios Konstitucijoje numatytas LDK statuso sumažinimas praktiškai taip ir nebuvo igyvendintas, o $1791 \mathrm{~m}$. spalio $20 \mathrm{~d}$. Seime prièmus Abiejų Tautų Tarpusavio İsipareigojimo aktą, laimėjo LDK savarankiškumo „tezé"17. Savo ruožtu Mečislovas Jučas ir šiuo metu laikosi nuomonès, kad net „Abipusis abiejų tautu isipareigojimas, priimtas lietuvių iniciatyva, jau nebegalejo pakeisti pagrindinès Gegužès 3 d. konstitucijos duotos [Respublikos unifikavimo] krypties" ${ }^{\text {"18. }}$.

Lietuvoje nusistovèjusị vienpusišką Gegužès 3-iosios Konstitucijos vertinimą kai kurie istorikai kritikuoja ir bando keisti vadinamąji Lietuvos istorijos didiji naratyvą. Pavyzdžiui, Alfredo Bumblausko kritika remiasi šiais argumentais: prie Konstitucijos rengimo prisidejo ir Lietuvos atstovai (pvz., Ignas Potockis), o Konstitucijos priešininkai (Targovicos konfederacijos rèmejjai) buvo Kotrynos II favoritai, privedę prie visiško Abiejų Tautų Respublikos žlugimo; Konstitucijai pritarẻ dauguma LDK pavietų seimelių; be to, $1791 \mathrm{~m}$. spalio $20 \mathrm{~d}$. Lietuvos delegacija Ketverių metų Seime išsireikalavo pataisos, pavadintos Abiejų Tautų Tarpusavio Issipareigojimu, kurioje jau buvo minimos abi tautos ir LDK ${ }^{19}$. Taip pat Eligijus Raila, siekdamas „reabilituoti“ Gegužès 3-iosios Konstituciją Lietuvos istoriografijoje, remiasi analogiškais argumentais, kad nè vienas Konstitucijos straipsnis nekalba specialiai apie Lietuvos panaikinimą, atvirkščiai - Konstitucijoje minimas terminas Respublikos valstybès (państwa Rzeczypospolitej) nurodo ị LDK. Be to, pasak autoriaus, Konstitucija buvo išversta ị lietuvių kalbą, o $1791 \mathrm{~m}$. spalio $20 \mathrm{~d}$. priimtas Abiejų Tautų Tarpusavio İsipareigojimas tapo „esmine konstitucijos pataisa“, todèl „kitaip negu istoriografinè versija, pabrëžusi Lietuvos išnykimą Karūnos glèbyje, būtų galima teigti,

17 Šapoka, A. Raštai. T. 2. Lietuva Reformu Seimo metu. Iki 1791 m. Gegužés 3 d. Konstitucijos. Vilnius: Vilniaus pedagoginio universiteto leidykla, 2008, p. 446.

${ }^{18}$ Jučas, M. Gegužès 3 d. konstitucijai. $1791 \mathrm{~m}$. gegužès 3 d. konstitucija. Vilnius: Vilniaus dailès akademijos leidykla, 2001, p. 10.

${ }^{19}$ Bumblauskas, A. Senosios Lietuvos istorija, 1009-1795. Vilnius: R. Paknio leidykla, 2005, p. 412. 
kad anuometine Lietuvos visuomenè išsaugojo šalies istorinio atskirumo ir savarankiškumo tradicija “20. Taigi, būtina atidžiau išnagrinèti minètus autorių argumentus dèl Gegužès 3-iosios Konstitucijos vertinimo Lietuvos valstybingumo kontekste, aptariant šiuos tris požymius: 1) Lietuvos vardo minejjimas Konstitucijos tekste, 2) termino Respublikos valstybés vartojimas Konstitucijos tekste ir 3) Konstitucijos vertimas $\mathfrak{i}$ lietuvių kalbą ${ }^{21}$.

1. Lietuvos istoriografijoje nusistovejusi nuomonè, kad Gegužès 3-iosios Konstitucijoje nèra minimas Lietuvos vardas. Vis dèlto nèra visiškai taip, nes Lietuva minima bent trijose vietose, tiesa, susijusiose išimtinai su asmenų titulais, t. y.: Preambulejje (monarcho titule), II straipsnyje (Lietuvos didžiojo kunigaikščio Vytauto titule) ir pasirašiusių Seimo atstovų tituluose. Pavyzdžiui, Preambuleje išvardijami monarcho Stanislovo Augusto titulai: „Stanislovas Augustas, iš Dievo malonès ir tautos valios Lenkijos Karalius, Lietuvos, Rusijos, Prūsijos, Mazovijos, Žemaitijos, Kijevo, Voluines, Podoles, Palenkès, Livonijos, Smolensko, Severo ir Černigovo Didysis Kunigaikštis <...>“. Nors Lietuvos vardas karaliaus, kaip Lietuvos didžiojo kunigaikščio, titule paminètas pirmu numeriu, tačiau formaliai žiūrint jis niekuo nesiskiria nuo Palenkes ar Černigovo, todèl Lietuvos valstybingumą čia sunku ižvelgti. Antra, Lietuva paminèta Konstitucijos II straipsnyje, kuriame, išvardijant bajorams suteiktų i̇vairių valdovų (pradedant Kazimieru Didžiuoju ir baigiant Žygimantu Augustu) privilegijas, šalia Jogailos

${ }^{20}$ Raila, E. Gegužès 3-iosios epocha. $1791 \mathrm{~m}$. Gegužès 3 d. Konstitucija. Vilnius, 2001, p. 74; Raila, E. Apie 1791 gegužés 3-iosios konstitucijq. Vilnius: Aidai, 2007, p. 65-68, 80-87.

${ }^{21}$ Būtina paminèti, kad iki šiol išsamiausia Lietuvos istorikų diskusija vertinant Gegužès 3-iosios Konstituciją vyko $2008 \mathrm{~m}$. spalio $10 \mathrm{~d}$. konferencijoje „1791 m. gegužès $3 \mathrm{~d}$. konstitucija Lietuvos istorijoje ir istorineje kultūroje" tuometiniame Vilniaus pedagoginiame universitete. Konferencijoje buvo kelti ne tik istoriniai, bet ir teisiniai klausimai, kurių rezultatais naudojamasi ir šiame straipsnyje. Konferencijos diskusijos ir apibendrinimai buvo publikuoti: Burbaitè, E., Karvelis, D., Ringytè, R. Dar kartą apie gegužès 3-iosios konstituciją. Istorija: mokslo darbai. T. 72 (2008), p. 104-108. 
paminètas ir „Vytautas, jo brolis, didysis Lietuvos kunigaikštis“. İdomu tai, kad visi Konstitucijoje išvardyti valdovai buvo Lenkijos valdovai karaliai, išskyrus Vytautą, kuris buvo tik Lietuvos valstybès valdovas Lietuvos didysis kunigaikštis. Vis dẻlto bandymų šią vietą interpretuoti kaip pripažịstančią valstybès dualizmą neleidžia po minètos nuostatos einantis sakinys, teigiantis, kad „<...> bajory luomo prakilnuma Lenkijoje pripažistame lygiaverčiu bet kokiam kur nors kitur naudojamam bajorystès laipsniui“. Todèl Vytauto Didžiojo, kaip Lietuvos didžiojo kunigaikščio, paminejjimą Konstitucijoje bajoru privilegijų kontekste galima trakuoti išimtinai istoriniu požiūriu. Pagaliau trečia vieta, kur Konstitucijoje paminèta Lietuva - ją pasirašiusių Seimo atstovų-signatarų tituluose: pirmiausia kunigaikščio Kazimiero Nestoro Sapiegos, kuris pasirašo kaip „Lietuvos artilerijos generolas ir LDK konfederacijos maršalka“, taip pat Kazimiero Konstantino Pliaterio, pasirašiusio kaip Trakų generolas kaštelionas ir „deputatas konstitucijai iš L. D. K.“, ir Jackaus Putkamerio, kuris pasirašè kaip Minsko vaivadijos pasiuntinys ir „deputatas konstitucijai iš LDK provincijos“22. Tačiau ir Konstitucijos signatarų lietuviški titulai negali būti vertinami kaip vienas iš Lietuvos valstybingumo akcentų, nes juose neatsispindi savarankiškas LDK teisinis statusas.

2. Kitas svarbus Konstitucijos teksto „lietuviškumo akcentas“, pabrèžiamas minètų autorių, galètų būti termino Respublikos valstybiu (daugiskaita) paminejjimas trijose Konstitucijos vietose. Pirmiausia ši nuostata užfiksuota III straipsnyje, kuriuo İstatymas „Mūsų karališkieji laisvieji miestai Respublikos valstybèse (w państwach Rzeczypospolitej) pripažistamas Konstitucijos sudetine dalimi“ (terminas Respublikos valstybés paminètas įstatymo pavadinime); IV straipsnyje, kuriuo suteikiama laisvė bet kuriems asmenims, naujai atvykusiems ar sugrižu-

${ }^{22}$ Abiejų Tautų Respublikos teritorija ị tris panašaus dydžio provincijas (Mažają Lenkiją, Didžiąją Lenkiją ir LDK) buvo suskirstyta jau 1775 m., tačiau šis suskirstymas, nors ir atsiradęs valstybès centralizacijos pagrindu, neturi būti vertinamas kaip panaikinantis LDK subjektiškumą bendroje valstybėje. 
siems ì Respublikos valstybes, ir V straipsnio, ịtvirtinančio tautos suvereniteto principą ir valdžių padalijimą, antrame sakinyje, kuriame teigiama: „<...> idant Respublikos valstybiu vientisumas, pilietine laisve ir visuomenès tvarka visam laikui išliktu pusiausvyroje, lenkų tautos valdyma turi sudaryti trys valdžios <... “". Nors Konstitucijoje niekur nèra nurodyta, kas yra Respublikos valstybès, niekam negalètų kilti abejonių, kad omenyje turimos Lenkijos Karalystè ir Lietuvos Didžioji Kunigaikštystė, minèto Konstitucijos teksto formuluotès leidžia manyti, jog dokumente vis dar grumiasi skirtingos naujos valdymo formos koncepcijos (konfederacinè ir centralizuota).

Kaip termino Respublikos valstybès interpretavimo šaltini galima pasirinkti ir $1791 \mathrm{~m}$. gegužès $5 \mathrm{~d}$. Seimo deklaraciją ${ }^{23}$. Kaip žinoma, gegužès $5 \mathrm{~d}$. Seime buvo antrą kartą balsuojama dèl Gegužès 3-iosios Konstitucijos; buvo priimta ir Seimo deklaracija, nurodanti, kaip Konstitucija turi būti igyvendinta ${ }^{24}$. Dèl šios priežasties deklaracija gali būti vertinama kaip tam tikras konstitucinis aktas dèl Konstitucijos įsigaliojimo tvarkos ir šiuo požiūriu laikomas jos sudedamąja dalimi. Todèl svarbi ir deklaracijos teksto analizè, galinti geriau paaiškinti Konstitucijos tekste vartojamas minètas sąvokas ir terminus.

Pirmiausia reikia pasakyti, kad šioje deklaracijoje Lietuvos Didžioji Kunigaikštystė yra paminèta reikšmiškai (ne tik tituluose): „<...> šiq priesaika duoti pavedame Lenkijos karūnos valstybèse, įskaitant Lietuvos D. K. (lenk. w państwach korony polskiej, $i$ W. X. litewskiego konsystujace). Gegužès 8 d. visose krašto bažnyčiose nustatome padèkos Dievui pamaldas už suteikta puikiq akimirką išsivaduoti Lenkijai iš užsienio priespaudos ir vidaus netvarkos <...>".

Taigi, šios deklaracijos kontekste paminètas Lenkijos karūnos vals-

${ }^{23}$ Gegužès $5 \mathrm{~d}$. Seimo deklaracijos teksto prasmėms pabrèžti taip pat buvo naudojama ir šios deklaracijos Juozo Tumelio lietuviško vertimo publikacija. Žr. Tumelis, J. Absakims Stonu surinktuju. Lietuvos istorijos metraštis. 1977, p. 105-106.

${ }^{24}$ Kochlewski, W. Ustawa Rzqdowa. Konstytucja 3 Maja 1791: pierwodruki. Warszawa, 2005, p. 3. 
tybiu, kaip ir Konstitucijos tekste kartais pasitaikantis terminas Respublikos valstybès nors ir išlaiko tam tikrą Lietuvos valstybingumo „svorį“, tačiau pastarajai jos interpretacijai reikalingos nuorodos i kitus istorinius teisinius šaltinius, esančius už Konstitucijos ribų, todẻl atsietai šis terminas negali būti pakankamas Lietuvos valstybingumo Gegužès 3-iosios Konstitucijos tekste argumentas. Be to, terminą Respublikos valstybès perskaityti lietuviškai dar labiau apsunkina terminas Lenkijos karūnos valstybès, paminètas Gegužès $5 \mathrm{~d}$. Seimo deklaracijoje. Todèl Konstitucijoje pasitaikantis terminas Respublikos valstybès geriausiu atveju galètų būti prilyginamas tokiam federaciniam subjektui kaip JAV federacinès valstijos (state) ar XIX a. pabaigoje suvienytos Vokietijos žemès (Länder). Tokị Respublikos valstybiu aiškinimą atitinka ir Miestų ístatymo teksto analizé, kurio pavadinime vartojamas terminas Respublikos valstybès šio ịstatymo tekste atskleidžiamas per terminus (LDK) provincija ar žemé $\dot{e}^{25}$.

3. Gegužès 3-iosios Konstitucijos vertimas ị lietuvių kalbą minimas taip pat dažnai, kaip ir argumentas dèl Konstitucijos lietuviško matmens. Reikia apgailestauti, kad dokumento vertimas iki šiol nèra rimtai ịvertintas ne tik Lietuvos kalbininkų, bet ir istorikų bei teisininkų. Dèl teisybès reikia pasakyti, kad 1978 m. (t. y. dar sovietmečiu) šis Konstitucijos vertimas (kartu su kai kuriais kitais Ketverių metų Seimo aktais) buvo publikuotas istoriko Juozo Tumelio, kuris parašè ir trumpą ižangą šiai publikacijai ${ }^{26}$. Kol kas tai vienintelis bandymas pasvarstyti apie galimus šio vertimo metus ir autorius. Beje, šis Konstitucijos vertimas taip ir liko rankraštyje - išspausdintas ir viešai išplatintas jis nebuvo. Autorius spèja, kad vertimas galejjo būti padarytas $1794 \mathrm{~m}$. Kosciuškos sukilimo metu, o kiti autoriai linkę vertimui suteikti net

${ }^{25}$ Miestu istatymo lietuvišką vertimą žr. $1791 \mathrm{~m}$. gegužès 3 d. Konstitucija. Vilnius, 2001, p. 35-52.

${ }^{26}$ Tumelis, J. Gegužès Trečiosios Konstitucijos ir Ketverių metų Seimo nutarimų lietuviškas vertimas. Lietuvos istorijos metraštis. 1977, p. 90-95; Tumelis, J. Prowa pastanawita treczio Dieno Moios, 1791 Miatu. Lietuvos istorijos metraštis. 1977, p. $95-105$. 
1791 ar vèlesnius - 1803 metus (juos, beje, pasak autoriaus, rodo rankraščio vandens ženklai) ${ }^{27}$. Žinoma, bet kuriuo atveju Gegužès 3-iosios Konstitucijos vertimas ị lietuvių kalbą yra pirmasis bandymas lietuvių kalba surašyti teisès akto tekstą - jame pirmąkart Lietuvos teisès istorijoje pavartoti tokie terminai kaip Seymas, Konstytucya, Lietuwa ir kt., kurie (nors ir ne šiuolaikinès lietuvių kalbos gramatikos transkripcija) yra vartojami ir dabartinejje teisinejje ir politinejje lietuvių kalboje, todèl ateityje būtina atlikti tolesni šio vertimo tyrimą, išsiaiškinant jo metus, vertẻją(-us) ir jo (jų) vartojamą tarmę. Kitais žodžiais tariant, tai pirmasis (nors ir nelabai vykęs) bandymas lietuvių kalbą iš buitinès terpès perkelti ị viešojo bendravimo lygmeni. Tai, kad Gegužès 3-iosios Konstitucija buvo oficialiai išversta ị lietuvių, o ne ị kitą Abiejų Tautų Respublikoje paplitusią kalbą, galima laikyti tam tikru LDK teisinio statuso savarankiškumo bendroje valstybejje išlaikymo požymiu. Vis dèlto šis Konstitucijos vertimas gali būti siejamas labiau su jos igyvendinimo procesu, vykusiu jau po priemimo, ir jis niekaip negali keisti Konstitucijos teksto (valstybės centralizacijos) prasmių.

Apibendrinant Gegužès 3-iosios Konstitucijos teksto analizę kartu su gegužès 5-osios Seimo deklaracija galima konstatuoti, kad Konstitucija nepanaikino LDK kaip administracinio teritorinio vieneto, tačiau konstituciškai užfiksavo tuo metu faktiškai sumažejusị jos statusą, kuris dèl istorinès tradicijos kartais ịvardijimas Respublikos valstybe (tiesa, kartu su terminu Lenkijos karūnos valstybès), o ne tik provincija, kraštu ar žeme. Be to, šis LDK teisinio statuso Gegužès 3-iosios Konstitucijoje sumažèjimas kyla pirmiausia iš to, kad suverenią tautą, kaip valstybės kūrẻją ir valstybę vienijančia jègą, Konstitucija įvardija lenkų tautą, o ne abi tautas, kaip buvo iprasta laikyti po Liublino unijos. Termino lenku tauta traktuoti išimtinai vien kaip pilietinès ar valstybinès tautos (analogiškai britų ar amerikiečių

${ }^{27}$ Tumelis, J. Gegužès Trečiosios Konstitucijos ir Ketverių metų Seimo nutarimų lietuviškas vertimas. Lietuvos istorijos metraštis. 1977, p. 92. Šio vertimo rankraštis (ar kopija) yra Lenkijos mokslų akademijos bibliotekoje Krokuvoje, jis mokslinėje literatūroje galèjo būti žinomas nuo 1906 m., kai buvo užregistruotas Lenkijos mokslų akademijos bibliotekos rankraščiu kataloge. Lietuvoje apie ši vertimą žinota jau tarpukariu. Rankraštis yra 34 × $22 \mathrm{~cm}$ formato sąsiuvinyje. 
tautoms) negalima, nes lenkų tauta nèra bendra respublikos tauta - tik viena iš abiejų tautų, užfiksuotų Liublino unijoje.

\section{Gegužès 3-iosios Konstitucija kaip sudètinès ATR $1791 \mathrm{~m}$. Konstitucijos dalis}

Prieš pradedant šią dalį reikètų konstatuoti, kad šiuolaikinès Lietuvos konstitucinès teisès mokslas kol kas dar neskyrè Konstitucijos analizei tinkamo dèmesio. Tai puikiai iliustruoja tiek Vilniaus universiteto, tiek Mykolo Romerio universiteto konstitucinès teisès vadovèliai. Pavyzdžiui, Egidijaus Šileikio studijoje „Alternatyvi Konstitucinè teisë“ apie Gegužès 3-iosios Konstituciją užsiminta vos keletu sakinių, ir tik išnašoje, kurioje teigiama, kad nè viename Konstitucijos straipsnyje „nekalbama apie Lietuva “ ir cituojamas jau minètas M. Jučo teiginys, kad Konstitucija „naikino Unija ir Lietuvos statusa valstybejje“28. Mykolo Romerio universiteto vadovèlyje „Lietuvos konstitucinè teise“ šiam dokumentui skiriamas vienas puslapis. Jame, be kita ko, teigiama, kad Gegužès 3-iosios Konstitucija yra „Lietuvos ir Lenkijos - Abieju Tautu Respublikos“, tačiau kitoje vietoje jau pripažistama, jog „,buvusi federacine valstybe Konstitucijoje verčiama viena Lenkijos karalyste, vientisa suverenia valstybe, joje $<\ldots>$ neminimas net Lietuvos vardas“ ir kad „Lietuvos padèti sušvelnino tik tu pat metu spalio $20 \mathrm{~d}$. LDK atstovu iniciatyva Seimo priimtas „Abiejų Tautų tarpusavio jzžadas“29.

Vertinant Gegužès 3-iosios Konstituciją ir jos santykį su Lietuvos teisès tradicija, įdomus ir naujas yra Jevgenijaus Machovenko požiūris: remda-

28 Šileikis, E. Alternatyvi konstitucine teisè. Vilnius: Teisinès informacijos centras, 2003, p. 45.

${ }^{29}$ Lietuvos konstitucinè teisè: vadovèlis. Vilnius: Mykolo Romerio universitetas, 2012, p. 109-110. Tiesa, net ir šios trumpos informacijos negalima priskirti Lietuvos konstitucionalistams, nes šis vadovėlio skyrius parašytas vieno žymiausių Lietuvos teisès istorikų - Mindaugo Maksimaičio. 
masis minètais istorikų tyrimais ${ }^{30}$, jis siūlo ị Gegužès 3-iosios Konstituciją žvelgti tik kaip ì vieną iš konstitucinių aktų, sudarančių sudètinę $1791 \mathrm{~m}$. (Ketverių metų Seimo priimtą) Konstituciją, j̣ kurią dar įeitų joje minimi: $1791 \mathrm{~m}$. kovo $24 \mathrm{~d}$. Seimeliu įstatymas, $1791 \mathrm{~m}$. balandžio $18 \mathrm{~d}$. vadinamasis Miestų ístatymas ir Spalio $20 \mathrm{~d}$. Abiejų Tautų Tarpusavio Issipareigojimas. Ši $1791 \mathrm{~m}$. konstitucinių aktų sąrašą dar galima papildyti minèta Gegužès 5 d. Seimo deklaracija. Reikia pripažinti, kad pirmuosius du isstatymus konstitucionalizuoja pati Gegužès 3-iosios Konstitucija, nes III straipsnyje teigiama, jog îstatymas „Mūsų karališkieji laisvieji miestai Respublikos valstybèse“ skelbiamas „šios Konstitucijos dalimi“, o šio ịstatymo II straipsnio 4 dalyje nurodyta, kad „visus ankstesnius įstatymus ir nuostatus, prieštaraujančius dabartiniam Miestu ìstatymui, panaikiname, o ši įstatyma skelbiame konstituciniu“. Panašiai ir Konstitucijos VI straipsnyje teigiama, kad anksčiau Seimo priimtą Seimelių įstatymą „ǐ̌kilmingai patvirtiname kaip esmini pilietiniu teisiu pagrinda" (Prawo o sejmikach <...> jako najistotniejsza zasadę wolności obywatelskiej, uroczyście zabezpieczamy) ${ }^{31}$. Kaip minèta, ì $1791 \mathrm{~m}$. Ketverių metų Seimo priimtų konstitucinių aktų sąrašą autorius siūlo įtraukti ir $1791 \mathrm{~m}$. spalio $20 \mathrm{~d}$. Abiejų Tautų Tarpusavio İsipareigojimą, kurị netgi siūlo laikyti „aukščiausiu“ konstituciniu aktu, nes, pasak autoriaus, „jo keitimas nenumatytas, jis turi galioti amžinai, o kitos

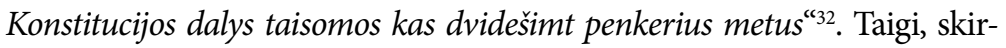

${ }^{30}$ Taip pat lenkų istoriku J. Bardachu, žr. Bardach, J. Konstytucja 3 maja 1791 r. a Zaręczenie Wzajemne Obojga Narodów. Warszawa, 2001.

31 Žr. Machovenko, J. Piliečio ir valstybès santykiai 1791 m. gegužès 3 d. konstitucijoje: paveldas ir pamoka. Lietuvos Respublikos Konstitucijos dvidešimtmetis: patirtis ir $i \check{s} s \bar{s}$ kiai. Vilnius, p. 8-10. Tiesa, autorius prie konstitucinių aktų priskiria ir pacta conventa.

32 Ten pat, p. 9. Abiejų Tautų Tarpusavio İsipareigojimo tekstą žr. $1791 \mathrm{~m}$. gegužès 3 d. Konstitucija. P. 55-58. Analogišką poziciją dèl Spalio 20 d. İsipareigojimo teisinio statuso (kad tai nėra Gegužès 3-iosios Konstitucijos pataisa ir kad jis hierarchiškai gali būti vertinamas kaip aukštesnis už minètą Konstituciją) jau buvo išsakę istorikai Robertas Jurgaitis ir Gintautas Sliesoriūnas minètoje 2008 m. spalio 10 d. konferencijoje „,1791 m. gegužès $3 \mathrm{~d}$. konstitucija Lietuvos istorijoje ir istorinèje kultūroje“. Žr. Burbaitè, E., Karvelis, D., Ringytė, R. Dar kartą apie gegužès 3-iosios konstituciją. Istorija: mokslo darbai. T. 72 (2008), p. 106. 
tingai nei iki šiol Lietuvos istoriografijoje vyravusi nuomonè, kad İsipareigojimą reikia laikyti Gegužès 3-iosios pataisa, jì galima laikyti viena iš sudètinių $1791 \mathrm{~m}$. Konstitucijos dalių, dar daugiau - net turinčiu aukščiausią teisinę konstitucinę galią.

Sudètinès Konstitucijos, sudarytos iš kelių konstitucinių aktų, samprata teisès moksle nèra nauja. Kaip pavyzdi galima pateikti Prancūzijos 3-iosios Respublikos Konstituciją, kurią sudare keli skirtingu metu priimti konstituciniai įstatymai. Be to, netgi i dabartinę Lietuvos Respublikos Konstituciją galima žiūrèti kaip ị susidedančią ne tik iš $1992 \mathrm{~m}$. Konstitucijos teksto, bet ir iš 1991 ir $1992 \mathrm{~m}$. konstitucinių aktų ir $2004 \mathrm{~m}$. konstitucinio akto „Dèl Lietuvos Respublikos narystès Europos Sąungoje“ (neminint isstatymo dèl Konstitucijos ịsigaliojimo tvarkos). Todèl Konstitucijos tekste minimi du anksčiau priimti ịstatymai turètų būti traktuojami kaip sudètinè $1791 \mathrm{~m}$. Konstitucijos dalis, nes po Gegužès 3-iosios Konstitucijos prièmimo jų statusas tapo konstitucionalizuotas ir jų nuostatų nebebuvo galima pakeisti, atitinkamai nepakeičiant Gegužès 3-iosios Konstitucijos III ir VI straipsnių. Kitaip tariant, nors minèti du įstatymai buvo priimti kaip ordinariniai, ar paprastieji, Seimo įstatymai (vartojant šiuolaikinę teisinę kalbą) dar prieš Gegužès 3-iosios Konstituciją, tačiau pastarajai savo blanketinemis nuostatomis ịtraukus juos ị valstybès „konstitucinị blokąa, šių dokumentų statusas susilygino su Konstitucijos teisiniu statusu ir jų nuostatų pakeitimui taip pat pradejo galioti 25 metų „apmąstymo“ laikotarpis. O Seimo deklaracija, priimta gegužès 5 dieną antrąkart balsavus dèl Gegužès 3-iosios Konstitucijos, galètų būti vertinama kaip Gegužès 3-iosios Konstitucijos įsigaliojimo tvarkos konstitucinis įstatymas. Todèl minètų trijų konstitucinių aktų (Seimelių ir Miestų įstatymų bei deklaracijos) konstitucinis statusas tiesiogiai kyla iš Gegužès 3-iosios Konstitucijos, kuri yra tarsi jų statuso ir veikimo „orbitos epicentras“.

Visai kitaip turètų būti vertinamas Spalio 20 d. Abiejų Tautų Tarpusavio İsipareigojimo konstitucinis statusas, kuris, palyginti su Gegužès 3-iosios Konstitucija ir minètais jos lydimaisiais konstituciniais aktais, yra išskirtinis. Tokị požiūrị galima paremti tuo, kad Gegužès 
3-iosios Konstitucijoje ir ją papildančiuose istatymuose užfiksuota tikrovė Ketverių metų Seimo buvo suprantama kaip pereinamojo pobūdžio realybè, kurią galima koreguoti pasikeitus gyventojų kartai, o Isipareigojime ịtvirtinta lenkų ir lietuvių tautų vienybẻ bendroje valstybejje trakuojama kaip amžinas ir nekeičiamas principas, prilygintas Liublino unijai ir ateities monarchų amžinai pacta conventa. Taigi, Spalio 20 d. Isipareigojimas, skirtingai nei anksčiau minèti konstituciniai aktai, nekyla iš Gegužès 3-iosios Konstitucijos, o ją viršija kaip turintis aukštesnị konstitucinị statusą, nes yra nekeičiamas ir „visiems laikams sudarytas “33. Vis dèlto Spalio 20 d. İsipareigojimą (sudètinèje Konstitucijoje) su Gegužès 3-iosios Valdymo ịstatymu susieti leidžia İsipareigojimo teksto nuoroda $\mathfrak{i}$ "Valdymo įstatymą" ir ten pateikta jo nauja interpretacija - jis turi tarnauti „Lenkijos Karūnai ir Lietuvos Didžiajai Kunigaikštijai“.

Jau minèta, kad Seimelių ir Miestų įstatymų bei Gegužès $5 \mathrm{~d}$. Seimo deklaracijos, kaip $1791 \mathrm{~m}$. konstitucinių aktų, tekstų analizė nerodo aiškių ir vienareikšmių LDK valstybingumo ar teisinio subjektiškumo prasmių, todèl esminę reikšmę šiame kontekste turi tik Spalio 20 d. Abiejų Tautų Tarpusavio Issipareigojimo aktas, kuris yra paskutinis Ketverių metų Seimo konstitucinis aktas, įeinantis ị sudètinę 1791 metų Konstituciją. Pirmiausia İsipareigojimo konstitucinị pobūdị rodo tai, kad jis priimtas visais balsais ir ji pasirašè išrinkti „deputatai konstitucijai“. Tačiau svarbiausia yra tai, kad İsipareigojimo akte šalia termino Lenkijos Respublika, kaip bendra tèvyne, yra aiškiai ir nedviprasmiškai vartojamas terminas „mūsų valstybès - Lenkijos Karūnos ir Lietuvos Di-

${ }^{33}$ Toks požiūris ị Konstituciją, kurioje skirtingos jos nuostatos ar dalys turi skirtingą konstitucinę teisinę reikšmę, nėra naujas. Kaip antai $1991 \mathrm{~m}$. konstitucinis ịstatymas „Dèl Lietuvos valstybės“, kuris yra sudètinè 1992 m. Lietuvos Respublikos Konstitucijos dalis, yra praktiškai nekeičiama konstitucinė vertybė, nes ją pakeisti galima tik referendumu, kai už tai pasisakytų daugiau nei 3/4 rinkimų teisę turinčių piliečių. O kitos $1992 \mathrm{~m}$. Konstitucijos nuostatos (išskyrus I ir XIV skyrių) gali būti keičiamos Seime 2/3 balsų dauguma. Nekeičiamų konstitucijos nuostatų turi ir 1948 m. Italijos Konstitucija ar 1949 m. Vokietijos Pagrindinis İstatymas ir kt. 
džiosios Kunigaikštystès“, be to, skirtingai nei Gegužès 3-iosios Konstitucijoje, jau kalbama ne apie lenkų tautą, o apie „abi - Lenkijos Karūnos ir Lietuvos Didžiosios Kunigaikštystès tautas“. Galiausia, kaip minèta, Spalio 20 d. Issipareigojime ir Gegužès 3-iosios Konstitucija perskaitoma Liublino unijos „dvasioje ${ }^{\text {“34, }}$, t. y. traktuojama ne kaip centralizuotai suvienijanti du savarankiškus subjektus ị vienos tautos Respubliką ar Lenkijos Karūną, o kaip „tarnaujanti visai mūsų valstybei - Lenkijos Karūnai ir Lietuvos Didžiajai Kunigaikštijai“. Taigi, dokumente nustatytą LDK teisinị statusą galima ịvardyti kaip tam tikrą konfederacinès valstybės subjektiškumą, pagal kurị abiejų subjektų yra valdoma bendra kariuomenė ir iždas, o LDK paliekama viešųjų Lietuvos pajamų kasa bei atskiras teismas (Respublikos) Iždo komisijos byloms, susijusioms su Lietuva, nagrinèti.

Apibendrinant šią dalị konstatuotina, kad visus minètus penkis konstitucinius aktus galima laikyti sudètinèmis $1791 \mathrm{~m}$. Konstitucijos dalimis, tačiau šią sudètinę $1791 \mathrm{~m}$. Konstituciją traktuoti kaip „Abiejų Tautų Respublikos Konstituciją“ galima tik dèl 1791 m. spalio $20 \mathrm{~d}$. Seime priimto Abiejų Tautų Tarpusavio Isipareigojimo ${ }^{35}$. Dar daugiau, tik šio paskutinio konstitucinio akto kontekste visą sudètinę ATR $1791 \mathrm{~m}$. Konstituciją galima laikyti ir Lietuvos konstitucingumo istorijos dalimi.

$34,,<\ldots>$ pripažįstame tų tautų [Karūnos ir LDK] unijų akto straipsnius, taip pat jų pastovumą ir neliečiamumą šiuo aktu apsaugome $<\ldots>$ taip tvirtai ir stipriai, kaip yra Lenkijos Karūnos ir Lietuvos Didžiosios Kunigaikštystės unijų akte. Ir kadangi Mes, Karalius, visa tai laikome savo pactorum conventorum straipsniu, tad ir Mūsų ipèdiniams, privalésiantiems prisiekti, visa tai norime turèti ịtraukta inter pacta conventa (5 p.)“.

35 Tai, kad 1791 m. spalio 20 d. İsipareigojimas pakeitė Gegužès 3-iosios Konstitucijoje numatytą valstybès centralizacijos principą ir garantavo LDK subjektinị savarankiškumą, pripažįsta ir minètas lenkų istorikas Michałas Petrzakas: „Jednakże ustawy wykonawsze do konstytucji nie potwierdzaly faktu likwidacji podmiotowości ustrojowej Wielkiego Księstwa. Uchwalone jednomyślnie Zaręczenie Wzajemne Obojga Narodów utrzymało odrębności ustrojowe Wielkiego Księstwa, głównie w zakresie administracji i prawa“. Petrzak, M. Konstytucja 3 Maja 1791 roku. Warszawa: Wydawnictwo Sejmowe, 2011, p. 12. 


\section{Išvados}

1. Gegužès 3-iosios Valdymo įstatymas pagal savo turinį turi tam tikrų modernios konstitucijos bruožų (steigiamasis akto pobūdis, viršenybè ordinarinès teisès atžvilgiu, valstybės sandaros, ịskaitant valdžių padalijimą, ittvirtinimas, poslinkis žmogaus teisių plètimo link) ir todèl gali būti pagrịstai vadinimas konstitucija šiuolaikine prasme. Vis dèlto Gegužès 3-iosios Konstitucijos prièmimo metu nebuvo laikomasi Seimo konstitucijoms (juolab keičiančių privilegijose nustatytų valdovo ir bajorų pacta conventa nuostatas) būtinų prièmimo taisyklių, ji priimta skubos tvarka, apeliuojant i̇ ypatingą padèti valstybejje.

2. Gegužès 3-iosios Konstitucijos tekste formaliai lietuvišką matmenị atspindi: 1) Lietuvos Didžiosios Kunigaikštystès paminejjimas Stanislovo Augusto, Vytauto Didžiojo ir Konstitucijos signatarų tituluose; 2) termino Respublikos valstybių vartojimas ir 3) Gegužès 3-iosios Konstitucijos vertimas ị lietuvių kalbą. Tačiau minèti Konstitucijos terminai neatskleidžia savarankiško LDK teisinio statuso valstybeje, o (kol kas nenustatytos datos) Konstitucijos vertimas ị lietuvių kalbą negali būti vertinamas kaip galintis keisti Konstitucijoje vartojamas valstybę centralizuojančias ir savarankišką LDK statusą mažinančias sąvokas bei prasmes.

3. Gegužès 3-iosios Konstitucijos teksto analizė leidžia konstatuoti, jog ja nebuvo panaikinta LDK, kaip teritorinis administracinis vienetas, tačiau ji užfiksavo sumažèjusị LDK statusą iki Lenkijos Karalystès federacinio subjekto ar net centralizuotos valstybès regiono, o joje pasitaikantis terminas Respublikos valstybès (šalia terminų Respublikos kraštai, žemès, provincijos) geriausiu atveju galètų būti prilyginamas tokiam federaciniam subjektui kaip JAV federacinès valstijos ar Vokietijos žemès.

4. Gegužès 3-iosios Konstitucijos (dèl steigiamojo pobūdžio valstybę centralizuojančių nuostatų) negalima vienareikšmiai vadinti Abiejų 
Tautu Respublikos Konstitucija, nes ji ne tik fiksavo, bet ir steigė naują politinę visuomeninę tikrovę, nepripažįstančią Lietuvos Didžiosios Kunigaikštystès suverenaus teisinio statuso, konstituciniu suverenu (šalia karaliaus) įvardydama lenku tautą.

5. I $1791 \mathrm{~m}$. Konstituciją galima žvelgti kaip ì sudètinę Konstituciją, kurią be Gegužès 3-iosios Valdymo ịstatymo ir Gegužès 5-osios Seimo deklaracijos sudarytų $1791 \mathrm{~m}$. kovo $24 \mathrm{~d}$. Seimelių istatymas, $1791 \mathrm{~m}$. balandžio $21 \mathrm{~d}$. Miestų îstatymas bei Spalio $20 \mathrm{~d}$. Abiejų Tautų Tarpusavio Issipareigojimo aktas. Pastarasis konstitucinis aktas yra ne tiek Gegužès 3-iosios Konstitucijos pataisa, kiek savarankišką statusą 1791 m. Abiejų Tautų Respublikos Konstitucijoje turintis konstitucinis aktas. Jei pirmiems trims konstituciniams aktams konstitucini statusą suteikia Gegužès 3-iosios Konstitucija, tai Spalio 20 d. İsipareigojimo (aukštesnio už kitus keturis aktus) konstitucinis statusas kyla tiesiogiai iš jo teksto reikšmių ir prièmimo procedūros.

6. Tik $1791 \mathrm{~m}$. spalio $20 \mathrm{~d}$. Abiejų Tautų Tarpusavio İsipareigojimo aktą ittraukus ị sudètinę Abiejų Tautų Respublikos 1791 m. Konstituciją, pastarają galima laikyti Lietuvos konstitucingumo istorijos dalimi, nes Lietuvos Didžioji Kunigaikštyste joje paminėta kaip lygiavertis Abiejų Tautų Respublikos subjektas, o ne tik kaip Respublikos ar Lenkijos karūnos provincija ar federacinė teritorija. Beje, analogiška pozicija atsispindi ir Lietuvos Respublikos Seimo $2011 \mathrm{~m}$. balandžio 28 d. rezoliucijoje „Dèl Gegužès trečiosios konstitucijos su Abiejų Tautų Tarpusavio İžadu 220-ųjų metinių“, kurioje teigiama, kad „pirmoji moderni rašytinè Konstitucija Europoje“ yra „Gegužés trečiosios Konstitucija su Abieju Tautu tarpusavio jž̆adu“. 


\title{
CONSTITUTION OF MAY 3, 1791 AND LITHUANIAN CONSTITUTIONAL TRADITION
}

\author{
VAIDOTAS A. VAIČAITIS
}

\section{Summary}

Keywords: Constitution; Seimas; Lithuania; Commonwealth of Two Nation; 1791.

This article is devoted to analyze the constitution of May 3,1791 - from legal point of view trying to find any touch points with Lithuanian statehood and constitutional history. That kind of survey is needed, because previous studies of this document in Lithuania have been exclusively done by historians but not legal (constitutional) scientists. The author firstly analyzes the question, whether this document might be considered as constitution through theory of modern constitutionalism, then the references to "Lithuania" in the text of the constitution are analyzed in order to reveal their meaning and lastly, the new concept of "constituent 1791 Constitution of Commonwealth of Two Nations" is offered, which through inclusion in it, especially,
Mutual Engagement of Two Nations (pol. Zaręczenie Wzajemne Obojga Narodów) adopted in October 20, 1791 - might be considered as a part of Lithuanian constitutional history. Therefore, the author suggests that this constituent 1791 Constitution might be consisted of 5 constitutional acts: 1) May 3 constitution, 2) Seimas Declaration of May 5, 3) April 21, 1791 Free royal cities act (pol. Miasta Nasze Królewskie Wolne w Państwach Rzeczypospolitej), 4) March 24, 1791 Act on local legislative councils' (pol. Prawo o Sejmikach) and 5) Mutual Engagement of Two Nations (pol. Zaręczenie Wzajemne Obojga Narodów). The article ends with some conclusions for contemporary Lithuanian constitutional legal science.

Iteikta $2013 \mathrm{~m}$. gegužès $30 \mathrm{~d}$. 